Silver, E. A. and Barnard, W. D., 1971. Pleistocene tectonics of the Washington continental slope. Geol. Soc. Am. Abst. 3(2), 193.

Spigai, J. J., 1971. Marine geology of the continental margin off southern Oregon. Ph.D. Thesis, Oregon State University, Corvallis.
Snavely, P. D., MacLeod, N. S., and Wagner, H. C. (in press). Miocene tholeiitic basalts of coastal Oregon and Washington and their relation to coeval basalts of the Columbia Plateau. Bull. Geol. Soc. Am.

\title{
PART B: SITE SURVEY OF PAUL REVERE RIDGE WEST OF NORTHERN VANCOUVER ISLAND
}

\author{
Richard Couch, School of Oceanography, Oregon State University, Corvallis, Oregon \\ and \\ Richard Chase, Department of Geology, University of British Columbia, Vancouver, British Columbia
}

Figure 1 shows the location of DSDP Site 177 and the site survey area off the northwest coast of Vancouver Island. The site is located in the Scott Islands fracture zone physiographic province (McManus, 1967a-b; Couch, 1969a-b; Dehlinger et al., 1971). The Scott Islands fracture zone, approximately $200 \mathrm{~km}$ long and $80 \mathrm{~km}$ wide, generally parallels the continental shelf and extends from on the continental shelf to the abyssal sea floor. Bathymetric studies of the region (Gibson, 1960; Hurley, 1960; McManus, 1964; Chase, Menard, and Mammerickx, 1970) show two long narrow ridges trending northwestsoutheast with relatively flat floor between (Figure 2). The westernmost ridge, Paul Revere Ridge (McManus, 1964), extends approximately $130 \mathrm{~km}$ northwest from $40^{\circ} 50^{\prime} \mathrm{N}$, $129^{\circ} 00^{\prime} \mathrm{W}$ to $50^{\circ} 30^{\prime} \mathrm{N}, 130^{\circ} 15^{\prime} \mathrm{W}$ and delineates the western boundary of the fracture zone. The region between Paul Revere Ridge and the continental shelf, termed the Winona Basin (Tiffen, Cameron, and Murray, 1972), is approximately 2000 meters below sea level and contains Winona Ridge, a broad ridge of relatively gentle relief subparalleling Paul Revere Ridge.

At its northwestern end, Paul Revere Ridge merges into the southeastern end of the two Dellwood knolls. Bertrand (1972) postulates the northwestern knoll to be an active center of sea floor spreading. Explorer Ridge, also a postulated active center of sea floor spreading, terminates at its northeastern end at approximately the mid-point of Paul Revere Ridge. At the southeastern end, Paul Revere Ridge diminishes in height and terminates in the vicinity of a submarine channel which runs south out of Winona Basin. DSDP Site 177 is located at the north end of Paul Revere Ridge.

Figure 3 shows that the pronounced magnetic anomalies (Raff and Mason, 1961; Couch, 1969) associated with sea floor spreading terminate along the west flank of Paul Revere Ridge and that the Scott Islands fracture zone exhibits very small amplitude magnetic anomalies. Vine's
(1966) interpretation of the magnetic ages of these anomalies suggests the oceanic crust southwest of Paul Revere Ridge is late Pliocene or younger.

Sea floor spreading adjacent to Paul Revere Ridge appears to occur at a center approximately $10 \mathrm{~km}$ south of Site 177 and approximately $30 \mathrm{~km}$ north of the main axial trough of Explorer Ridge. The high heat-flow values observed by Lister and Davis (Srivastava et al., 1971) and very fresh basalt dredged from a valley near $50^{\circ} 20^{\prime} \mathrm{N}$ latitude, $130^{\circ} 10^{\prime} \mathrm{W}$ longitude support this interpretation. Although high heat-flow values are observed in postulated spreading centers immediately west of Paul Revere Ridge, (Couch, 1970; Srivastava et al., 1971) approximately normal heat flow is observed in Winona Basin (Couch et al., 1970, unpublished).

The Scott Islands fracture zone (Figure 4) exhibits free-air gravity anomalies between -80 and $-160 \mathrm{mgl}$. Couch $(1969 b)$ interpreted the gravity anomaly magnitudes and pattern as suggesting a complex graben or a group of downfaulted blocks which were subjected to right-lateral shear. Figure 5 shows a crustal and subcrustal cross section which passes approximately through the gravity minimum and intersects Paul Revere Ridge and the continent approximately orthogonally. The anomaly is interpreted as caused by a crustal block downdropped approximately 6 $\mathrm{km}$ with the resulting graben filled with light sediments, possibly glacial till. The magnitude of the anomaly suggests the fracture zone is a major structural feature which may extend into the upper mantle. The relatively light $(\rho=$ 3.18) material postulated in the upper mantle in the section is associated with the Explorer Ridge complex.

Continuous seismic profiling shows Paul Revere Ridge changes its character from north to south. On the north, in the area of Site 177 (Figure 6), it appears to form part of the Revere-Dellwood transform-fault zone joining Explorer Ridge to the Dellwood spreading center. Here, it is cut by numerous faults, steeply dipping or vertical, and probably 


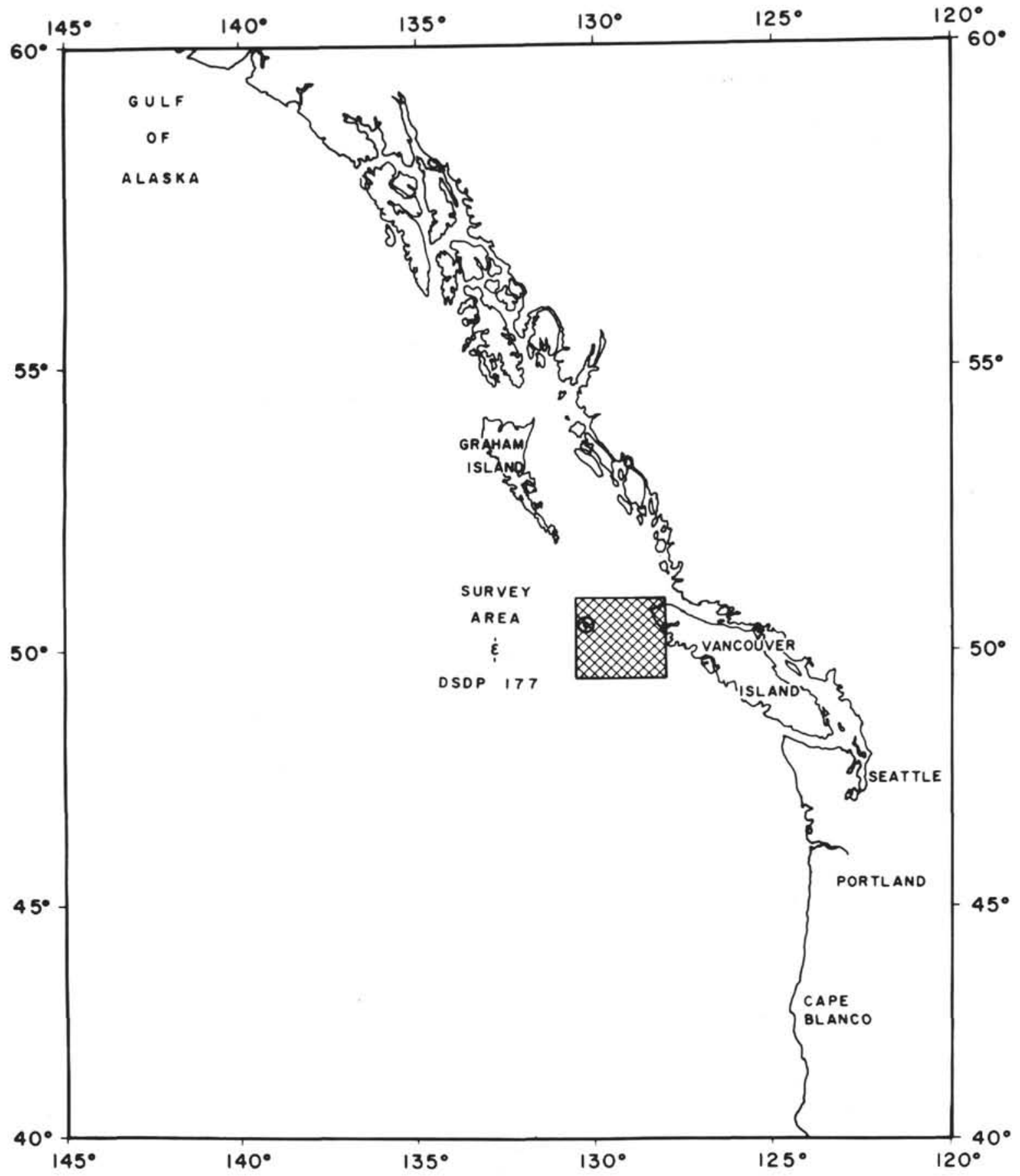

Figure 1. Map showing location of Site 177 and area of site survey.

with a right-lateral sense of displacement. To the south, the faults are not so obvious, and may surface on the southwest flank of the ridge (Figure 7). Both in its northern and southern sectors, the ridge appears to be a basement block tilted up to the southwest. Above the basement, which dips northeast into Winona Basin, lies a sequence of sedimentary strata which also dip northeast. In the north, this sequence thickens steadily towards the basin under the ridge flank from $0.5 \mathrm{sec}$ to greater than $1.0 \mathrm{sec}$; in the south, little thickening occurs on the ridge flank, the sequence being about $0.25 \mathrm{sec}$ thick.
The composition of the northeasterly dipping acoustic basement beneath Paul Revere Ridge is not certainly known. Certain inferences are possible from the composition of dredge hauls. A dredge haul from the southeastern end of the ridge, where a reflection profile shows the sedimentary veneer to be thin or absent, recovered basalt. Dredging up the southwestern flank of the ridge recovered basalt and a green rock which may be serpentinite. Hence the basement may be oceanic crust. The absence of linear magnetic anomalies suggests that if the crust is indeed oceanic, it is considerably older than the crust of Explorer 


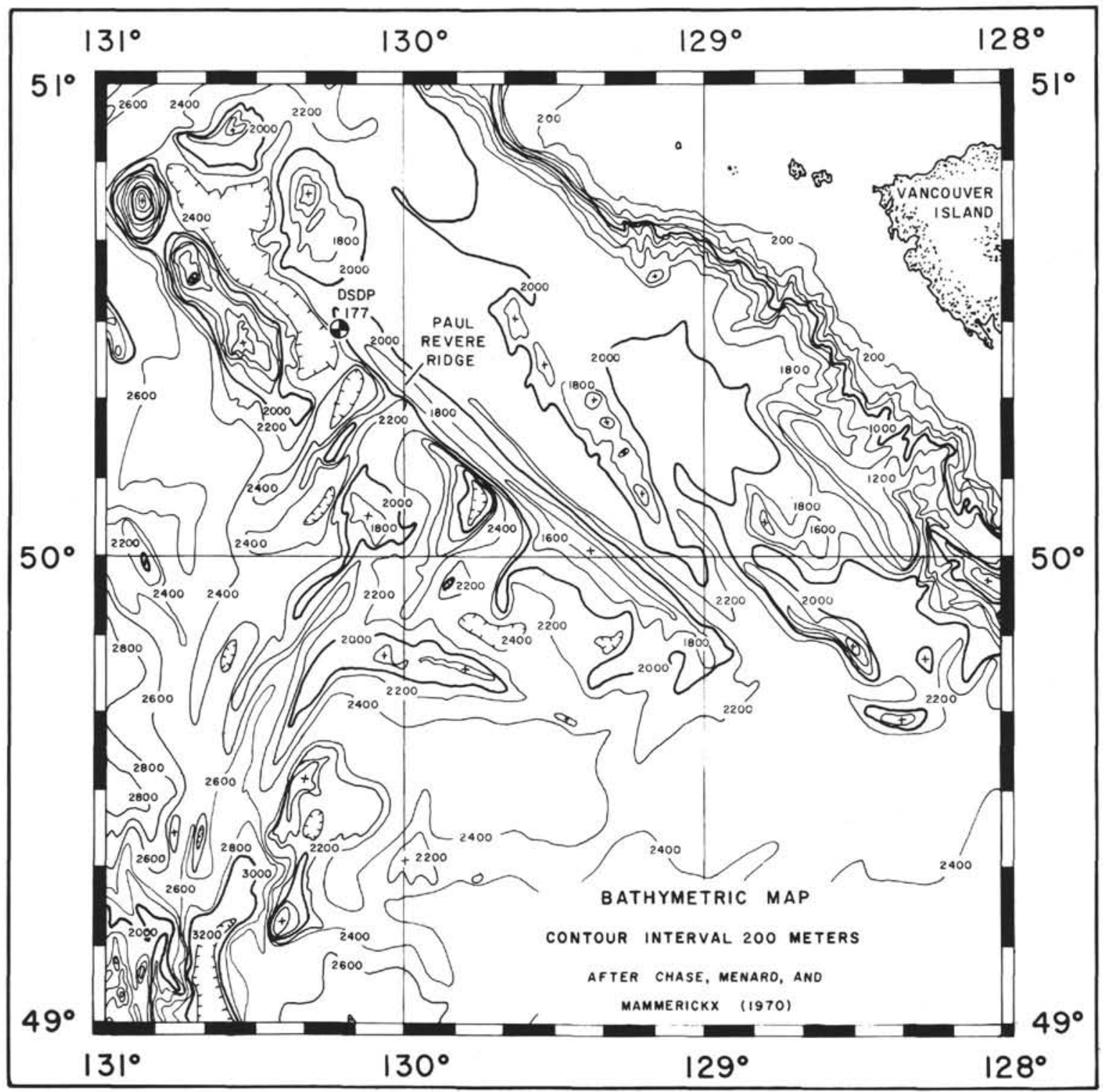

Figure 2. Bathymetric map of survey area (after Chase, Menard and Mammerickx, 1970).

Ridge, and has had its original anomalies destroyed by heating, or fracturing, or both.

Some reflection profiles, however, contain evidence of obscure reflectors below the acoustic basement. This suggests the basement may be layered lithified sedimentary or metamorphic rock. The actual composition of the basement has important implications for the origin and development of Winona Basin. If the basement is oceanic, the Winona Basin sequence is probably a deformed sedimentary submarine fan which developed at or near the foot of the continental slope. If the basement is metamorphic, Paul Revere Ridge may be a foundered block of continental material, and the Winona sequence may sit on top of similar material, or fill a depression formed when Paul Revere Ridge was rafted away from the continent.

The absence of evidence for shallow-water origin of the sediments encountered in DSDP Hole 177, and a gravity high over Paul Revere Ridge favors an oceanic composition for the basement of Paul Revere Ridge.

The magnitude and areal extent of the gravity anomalies, and the structures revealed by seismic profiling indicate the continental margin off northern Vancouver Island has undergone major tectonic modification. Figure 8 shows the margin off Vancouver Island is the site of the postulated triple junction between the Pacific, Juan de Fuca, and North American lithospheric plates. Interpretation of the magnetic anomalies, although different by different investigators (Pavoni, 1966; Vine, 1966; Peter and Latimore, 1969; Atwater, 1970), indicates that the tectonism extends from the Pliocene to the Holocene. Seismic profiling (Couch, 1969; Tiffen et al., 1972; Bertrand, 1972; McManus et al., 1972) and earthquake studies (Tobin and Sykes, 1968; Wetmiller, 1971) indicate recent and continuing deformation. The evolution of the 


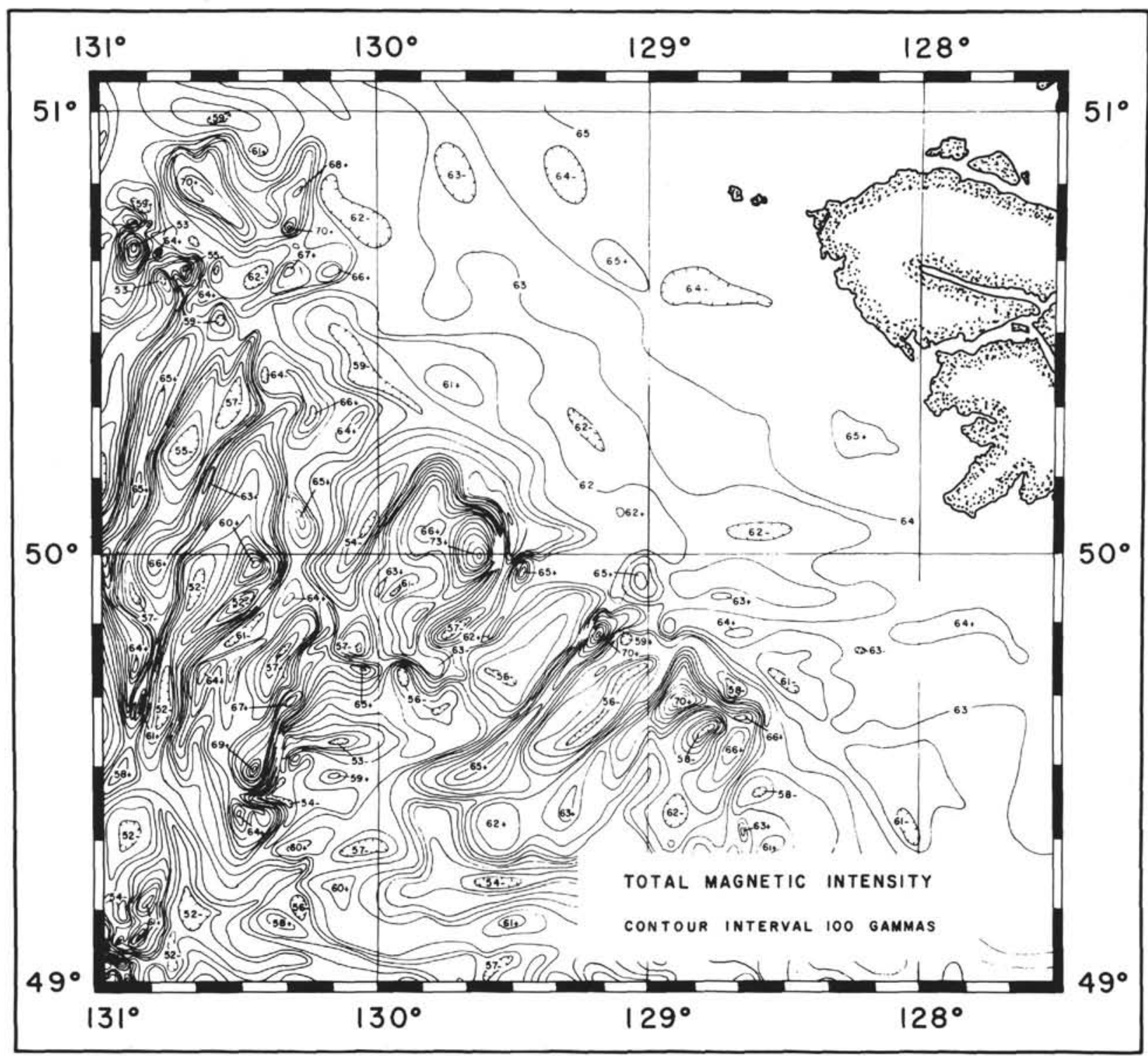

Figure 3. Total magnetic intensity map of survey area (after Raff and Mason, 1961).

postulated triple junction is not completely understood. Paul Revere Ridge may have formed along the structural discontinuity formed by the southeastern extension of the right-lateral Queen Charlotte Fault. The observed block faulting in this interpretation is a consequence of regional uplift and dilation caused by either the formation of Explorer Ridge or the northwestward migration of Explorer Ridge during late Pliocene time. Alternately, Paul Revere Ridge, formerly a deep-sea fan, may have formed as a result of underthrusting of the continental margin by the small sector of Juan de Fuca Plate north of the Savonco Fracture Zone. The underthrusting is a consequence of either large plate interaction or internal deformation of the northern end of the Juan de Fuca Plate.

\section{REFERENCES}

Atwater, T., 1970. Implications of plate tectonics for the Cenozoic tectonic evolution of Western North America. Bull. Geol. Soc. Am. 81, 3513.
Bertrand, W. G., 1972. A geological reconnaissance of the Dellwood Seamount Area, Northeast Pacific Ocean, and its relationship to plate tectonics. Unpublished M.S. thesis, the University of British Columbia, $151 \mathrm{p}$.

Chase, R. L., Menard, H. W., and Mammerickx, J., 1970. Bathymetry of the North Pacific. Scripps Institution of Oceanography and Institute of Marine Resources. (Map)

Couch, R. W., 1969a. Gravity and structures of the crust and subcrust west of Washington and British Columbia. Ph.D. dissertation, Oregon State University, Corvallis.

$1969 \mathrm{~b}$. Gravity and structure of the Scott Island fracture zone (abstract). Trans. Am. Geophys. Union. $50(11), 633$.

1970. Geophysical observations of Explorer Ridge and Trough (abstract). Trans. Am. Geophys. Union. 51(4), 316.

Couch, R. W., Gemperle, M., and Johnson, S., 1970. Heat flow measurements in the Northeast Pacific. Unpublished geophysical report, Oregon State University, Corvallis. 


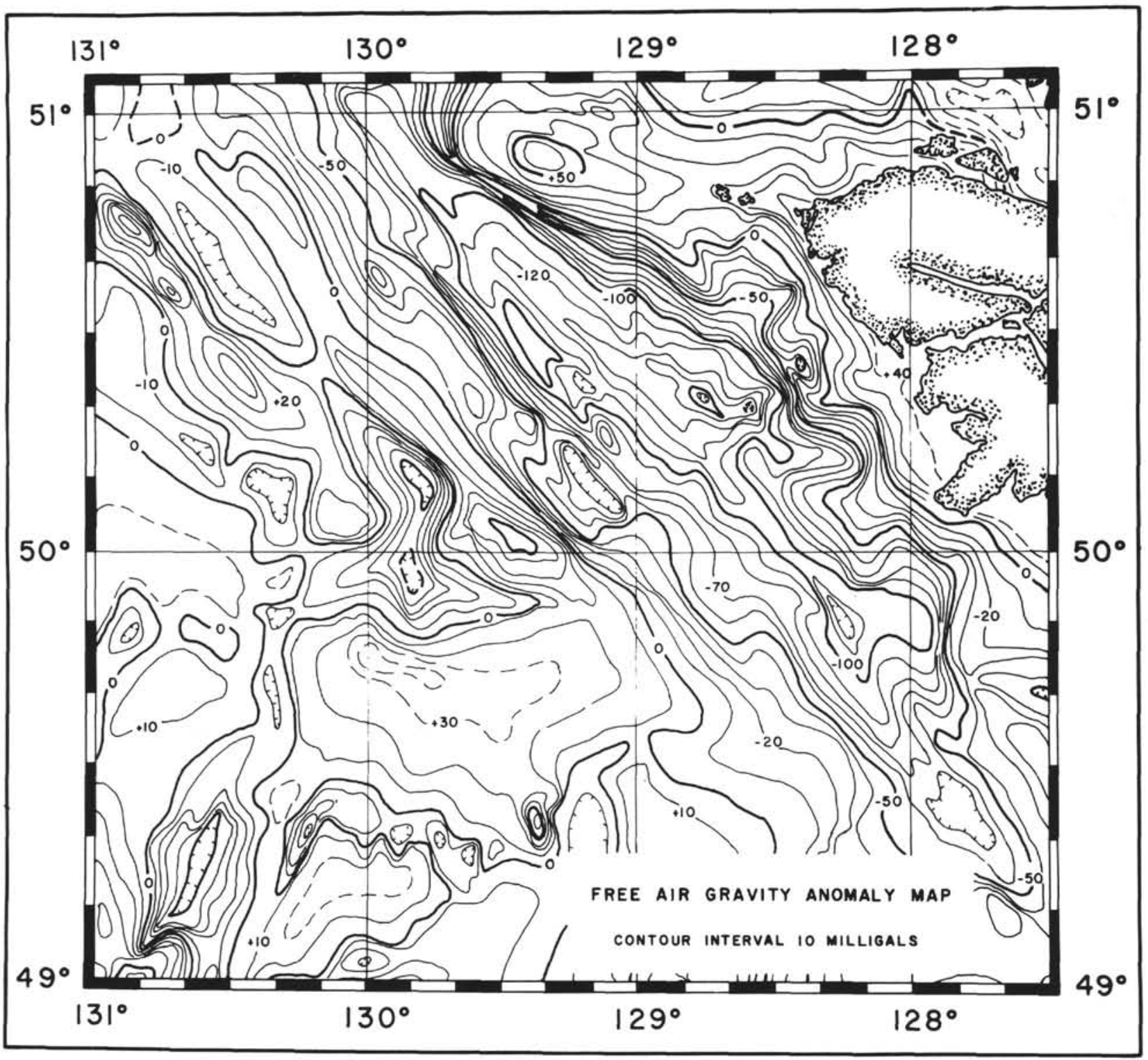

Figure 4. Free-air gravity map of survey area (after Couch, 1969).

Dehlinger, P.; Couch, R. W.; McManus, D. A.; and Gemperle, M., 1971. Northeast Pacific structure. In The Sea, Vol. 4. A. E. Maxwell (Ed.). New York (Wiley Interscience).

Gibson, W. M., 1960. Submarine topography in the Gulf of Alaska. Bull. Geol. Soc. Am. 71, 1087.

Hurley, R. J., 1960. The geomorphology of abyssal plains in the northeast Pacific Ocean. Scripps Institution of Oceanography Tech. Report (S10 Reference 60-7), $105 \mathrm{p}$.

McManus, D. A., 1964. Major bathymetric features near the coast of Oregon, Washington and Vancouver Island. Northwest Sci. 38, 65 .

McManus, D. A., 1967a. Classification of submarine physiography in the Gulf of Alaska. Northwest Sci. 41, 118.

McManus, D. A., 1967b. Physiography of Cobb and Gorda Rises, northeast Pacific Ocean. Bull. Geol. Soc. Am. 78, 527.
McManus, D. A.; Holmes, M. L.; Carson, B.; and Barr, S. M., 1972. Late quaternary tectonics, northern end of Juan de Fuca Ridge (Northeast Pacific). Mar. Geol. 12, 141.

Pavoni, N., 1966. Tectonic interpretation of the magnetic anomalies southwest of Vancouver Island. Pure Appl. Geophys. 63, 172.

Peter, G. and Latimore, R., 1969. Magnetic structure of Juan de Fuca-Gorda Ridge area. J. Geophys. Res. 74, 586.

Raff, A. D. and Mason, R. G., 1961. Magnetic survey off the west coast of North America, $40^{\circ} \mathrm{N}$ latitude to $50^{\circ} \mathrm{N}$ latitude. Bull. Geol. Soc. Am. 72, 1267.

Srivastava, S. P.; Barrett, D. L.; Keen, C. E.; Manchester, K. S.; Shih, K. G.; Tiffen, R. L.; Chase, R. L.; Thomlinson, A. G.; Davis, E. E.; and Lister, C. R. B., 1971. Preliminary analysis of geophysical measurements north of Juan de Fuca Ridge. Can. J. Earth Sci. 8, 1265.

Tiffen, D. L., Cameron, B. E. B., and Murray, J. W., 1972. Tectonics and depositional history of the continental 
R. COUCH, R. CHASE
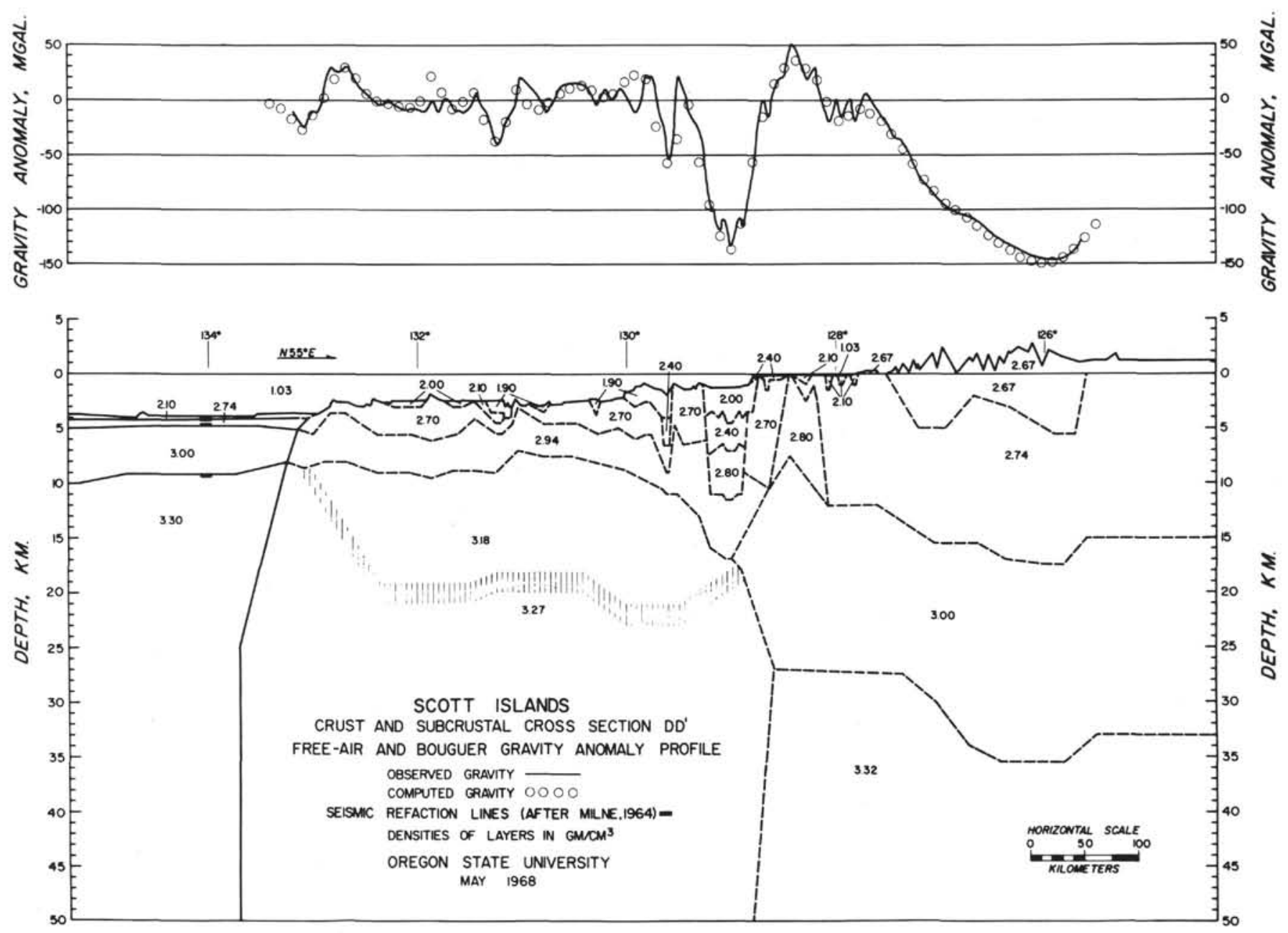

Figure 5. Crustal and subcrustal cross section through survey area. (Reproduced from Dehlinger et al., 1971, with permission of John Wiley and Sons.)

margin off Vancouver Island, British Columbia. Can. J. of Earth Sci. 9(3), 280.

Tobin, D. G. and Sykes, L. R., 1968. Seismicity and tectonics of the Northeast Pacific Ocean. J. Geophys. Res. 73, 3821 .
Vine, F. J., 1966. Spreading of the ocean floor: New evidence. Science. 154, 1405.

Wetmiller, R. J., 1971. An earthquake swarm on the Queen Charlotte Islands fracture zone. Bull. Seism. Soc. Am. 61(6), 1489. 


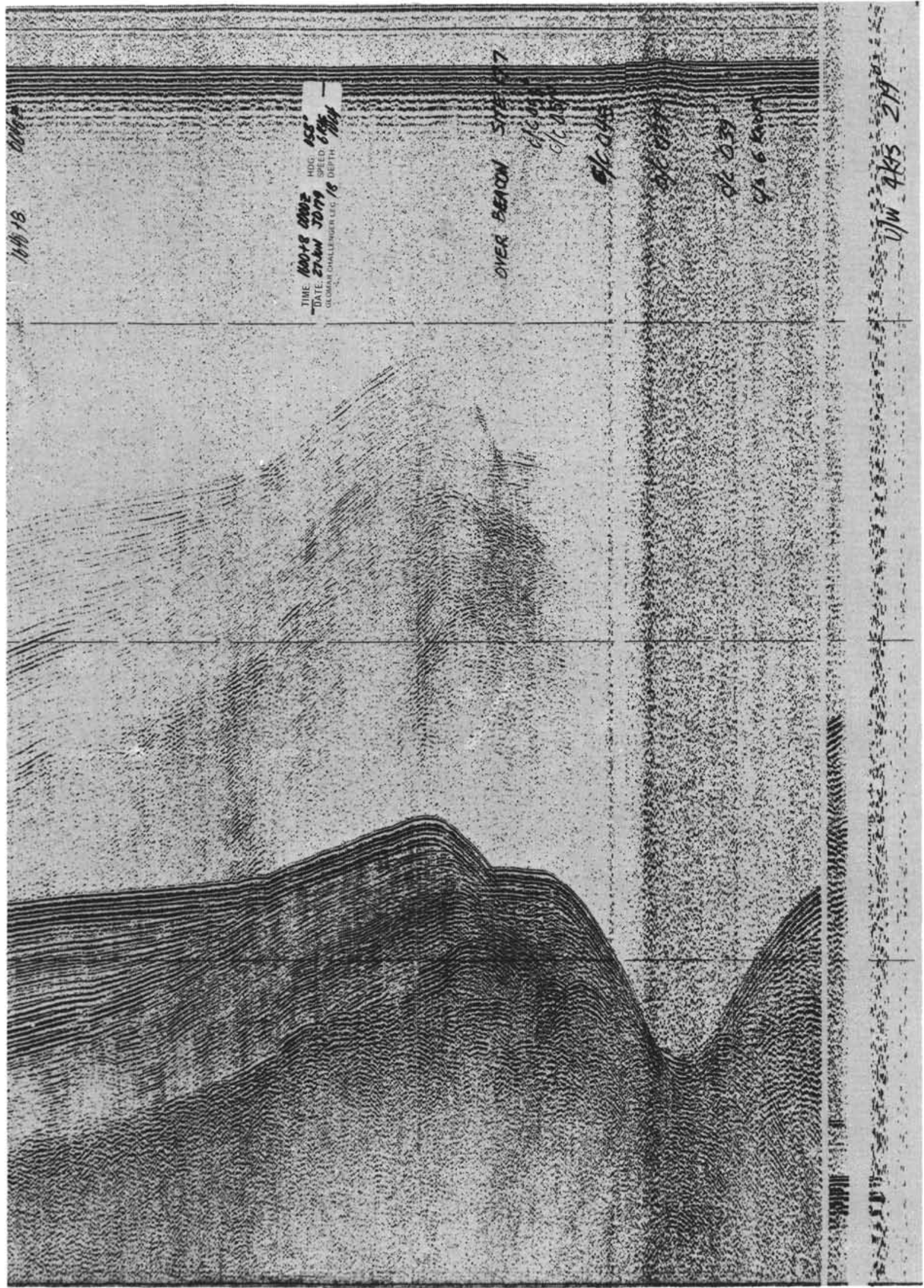

Figure 6. Seismic reflection profile of Site 177 (Glomar Challenger site report). 
R. COUCH, R. CHASE

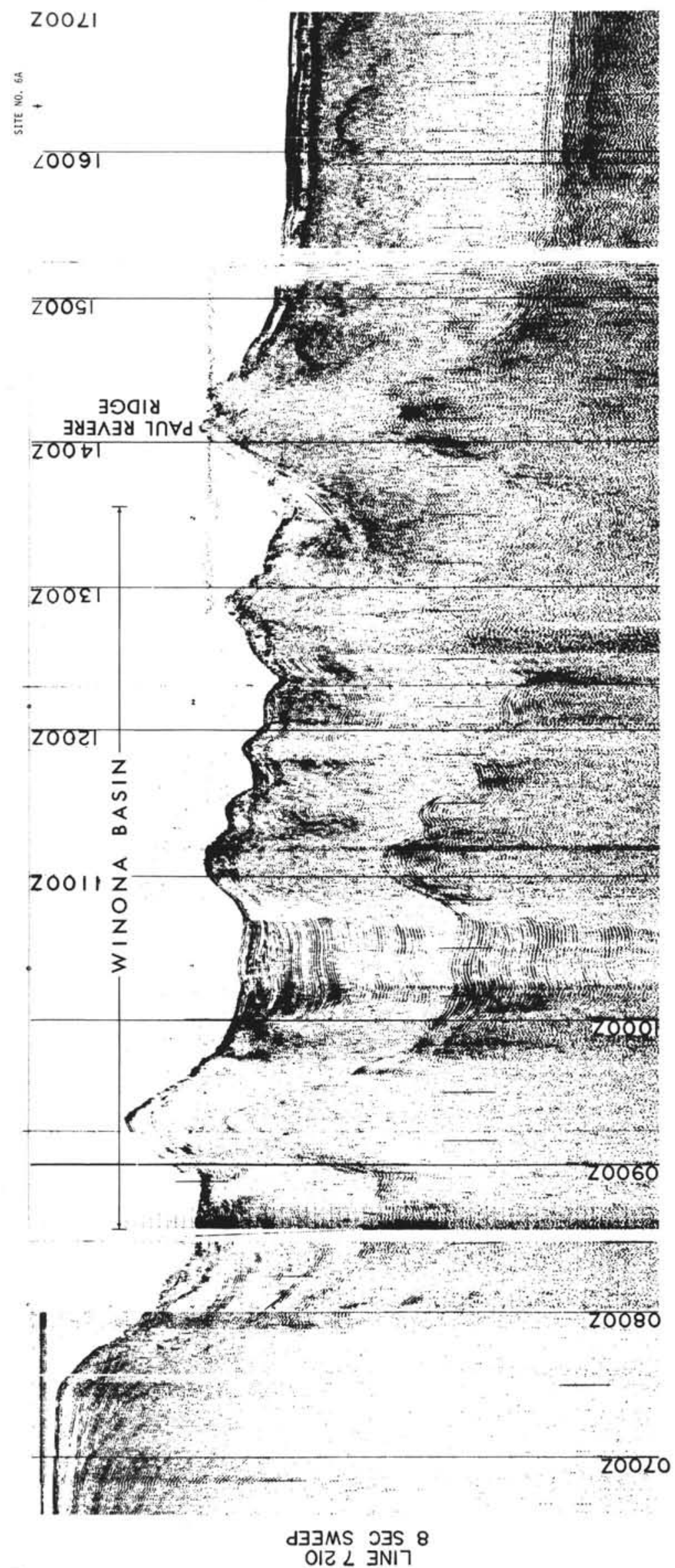

Figure 7. Seismic reflection profile of Paul Revere Ridge and Winona Basin (Hudson 70 line \#7). 


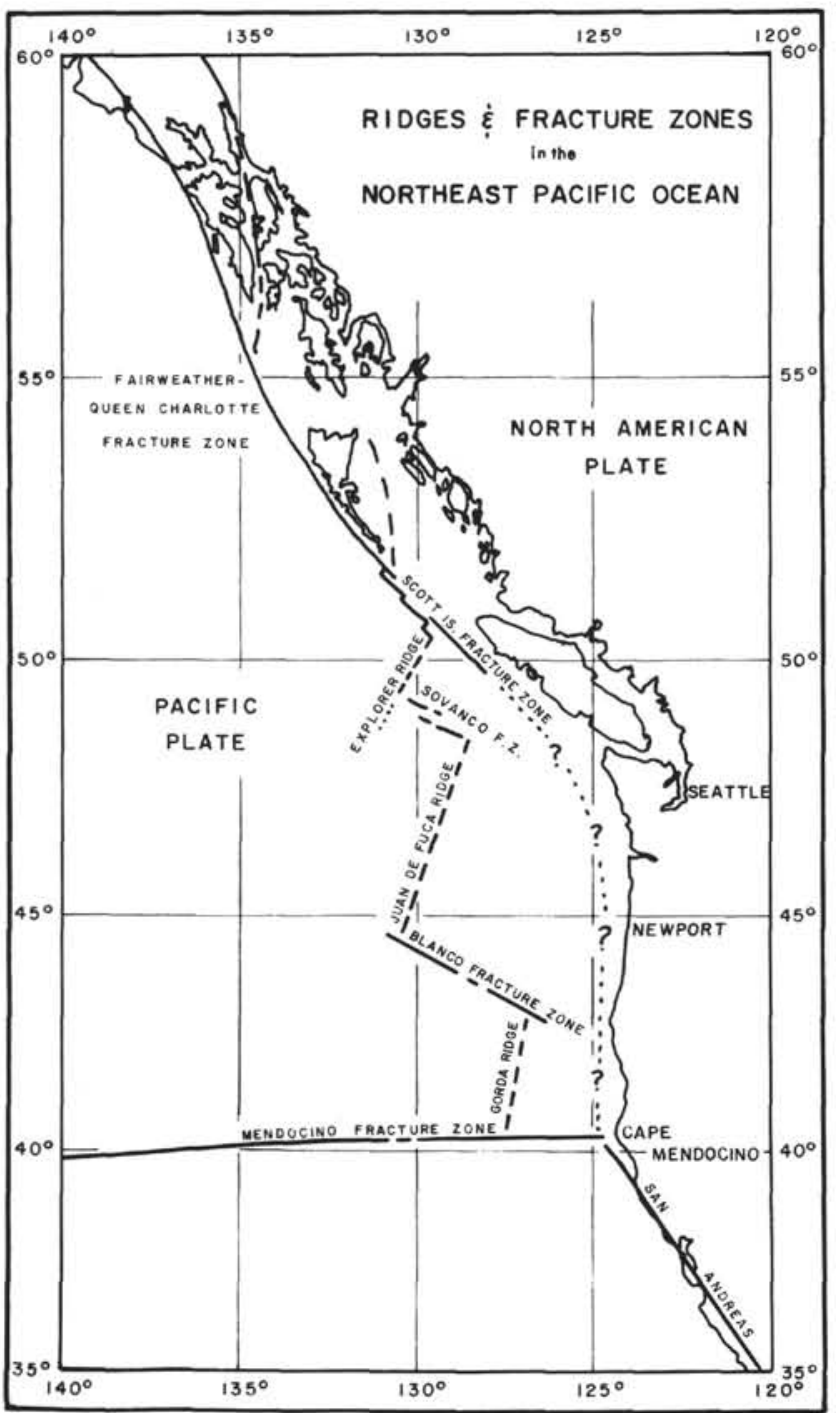

Figure 8. Tectonic map of the northeast Pacific Ocean showing ridge and fracture zone system in the vicinity of Site 177.

\section{PART C: SITE SURVEY ON THE TUFTS ABYSSAL PLAIN}

George Shor, John Grow, Harold Poelchau, Paul Liebertz, Robert Iuliucci and Sudi Karuse, Scripps Institution of Oceanography, La Jolla, California

Deep Sea Drilling Project proposed Site 18-8, on the Tufts Abyssal Plain, (not drilled) was surveyed by the R/V Melville from 7 July to July 10, 1970 (Figure 1). The site is located approximately $600 \mathrm{~km}$ west of the Juan de Fuca Ridge between the terminal ends of Moresby and Scott Channels (Figure 2). Regional magnetic studies suggest the site is near Anomaly 7 (Atwater, 1970). The site was proposed to study the biostratigraphy of the plain. Airgun reflection profiles and $3.5 \mathrm{kHz}$ echosounder records are used for stratigraphic interpretation of the area.

Topographically, the sea floor is essentially a flat plain dipping gently southwest with depths from 2260 fathoms in the northeast to 2295 fathoms in the southwest (Figure 3). Small nonlineated basement hills rise 50-150 fathoms 